\title{
İşyerinde Kişisel İnternet ve Teknoloji Kullanımı: Sanal Kaytarma
}

\author{
The Personal Internet and Technology Usage at the Workplace: Cyberslacking
}

\author{
Edip ÖRÜCÜ' ${ }^{1}$, Harun YILDIZ²
}

\begin{abstract}
ÖZET
Sanal kaytarma faaliyetleri, çalışanlar ve işletmeler üzerinde önemli negatif etkilereyol açabilmektedir. Ancak Türk literatürü sanal kaytarma faaliyetlerinin bu önemi konusunda oldukça sınırlı kalmıştır. Bu kapsamda araştırmada, akademik ve akademik olmayan üniversite personeli arasındaki sanal kaytarma faaliyetlerinin belirlemesi amaçlanmıştır. 151 anket aracılığıyla yapılan araştırmada, sanal kaytarma faaliyetleri özellikle demografik değişkenler açısından incelenmiştir. Bulgular, sanal kaytarma faaliyetlerinin çalışanların demografik değişkenleri açısından anlamlı farklııklar gösterdiğini ifade etmektedir. Ayrıca, araştırma sonucunda uygulayııılar ve çalışanlar için çeşitli önerilerde bulunulmuştur.
\end{abstract}

Anahtar Kelimeler: Sanal kaytarma, internet ve teknoloji kullanımı.

\section{GíRiş}

Sanal kaytarma genel olarak iş amaçlı kullanım için sunulmuş olan bilgisayar ve internet sistemlerinin kişisel amaçlar için kullanılması anlamına gelmektedir. İş yerinde internet kullanımı, iletişim uygulamalarına önemli kolaylıklar getirmektedir. Bu anlamda internet bağlantısı çalışanların birbirleri arasındaki iletişimi kolaylaştırmakla beraber, işyükü açısından da gereksiz işlemlerin azaltılmasına ya da ortadan kaldırılmasına imkân veren bir zemindir. Ancak internet ve bilgisayar kullanımı bu olanaklarının dışında artan oranda suistimal edilmekte ya da bilinçsiz kullanım yüzünden işletmeleri maliyet kayıpları ile yüz yüze bırakmaktadır. Amerikan Yönetim Derneği' nin yaptığı bir araştırmada işletme içerisindeki tüm internet faaliyetlerinin \%50'sinden fazlasının işletme dışı amaçlar için kullanıldığı belirlenmiştir (Greengard, 2000). Mobil aygıtlar (akıllı cep telefonları, tablet bilgisayarlar, e-readerler gibi) da bu amaçlarla kullanıldığında, süreç daha kontrol edilemez hale gelmektedir (Ovarec, 2002: 61).Sanal kaytarmaya çalışanları sürükleyen süreçlerin sosyolojik boyutu bir yana, sanal kaytarma iş ortamında önemli miktarda maliyet kayıplarına neden olan bir olgudur. Internet üzerinde gerçekleşen müstehcen içerikli

\begin{abstract}
The cyberslacking activities lead to serious negative impacts for employees and businesses. However, the Turkish literature is quite limited regarding this importance of cyberslacking/ cyberloafing activities. This study aims to explore the extent of cyberslacking/cyberloafing among university employees, both academic and non-academic. Through the use of 151 surveys the study particularly investigates cyberslacking/ cyberloafing from a demographic variables perspective. The findings suggest that cyberslacking/cyberloafing activities show significant variations according to employees' demographic variables. Furthermore, practical implications for both employees and practitioners are discussed.
\end{abstract}

Keywords: Cyberslacking (cyberloafing), internet and technology usage.

paylaşımların \%70' inin çalışma saatleri içerisinde gerçekleşmesi de işletmeleri hukuki yaptırımlar altına sokmakla birlikte, verilecek kararların mali yükümlülüğü de işletmeye ayrıca bir yükyükleyecektir (Staff Report, 2010). Saratoga Enstitüsü' nün ABD' de yaptığı bir araştırmada da katılımcıların \%56'sı yetişkin sitelerini ziyaret ettiğini ve internet üzerinden kumar oynadığını kabul etmiştir. Kurt (2011) tarafından yapılan araştırmada ise, katılımcıların \%38,6' sının ders saatleri içerisinde müzik indirdikleri saptanmıştır. Kalaycı (2010) tarafından yapılan araştırmada, katılımcıların \%51,2'sinin ders saatleri içerisinde müzik, yazılım, video indirme gibi amaçlarla sanal kaytarma yaptıkları belirlenmiştir. Özkalp vd. (2012) tarafından yapılan araştırmada ise katılımcıların $\% 34,8^{\prime}$ sinin müzik, film veya video indirdiği, \%26,6' sının yetişkin sitelerini ziyaret ettiği belirlenmiştir.

Türkiye' de 2012 yılı internet kullanım verilerine göre interneti işyerinde kullanma oranı \%33.8, kablosuz bağlantılar vasıtasıyla kullanım oranı \%5.9 olarak belirlenmiştir (TÜiK, 2012). 16-74 yaş grubundaki bireylerde bilgisayar ve internet kullanım oranları sırasıyla \%48.7 ve \%47.4 düzenli internet kullanan bireylerin oranı ise \%37.8' dir. $\mathrm{Bu}$ oranın önceki yıllara göre genel alt istatistiki 
verileri incelendiğinde, genel ve iş ortamındaki kişisel kullanım oranının arttığı gözlenmektedir. Gün geçtikçe kullanımı artan internet, bilgisayar ve mobil aygıtların kullanım politikaları belirlenmedikçe sanal kaytarma faaliyetleri daha kontrol edilemez hale gelmektedir. Çünkü kontrolsüz gücün işletme amaçlarına yönlendirilmediği sürece bir güç olmasından söz edilmesi zordur. Yol açtığı önemli verimlilik kayıpları ve bu alanda yapılan araştırmaların sınırlılığı düşünüldüğünde üzerinde dikkatle durulması gereken bir konu olarak ortaya çıkmaktadır. Bu öneme binaen hazırlanan çalışmada, üniversite çalışanlarının önemli ve önemsiz sanal kaytarma faaliyetlerini kullanma sıklığı ile demografik değişkenler arasındaki farklılıkların belirlenmesi ve sanal kaytarma konusunda ileride yapılacak araştırmalara bir zemin hazırlaması amaçlanmaktadır.

\section{KURAMSAL ÇERÇEVE}

\subsection{Sanal Kaytarma}

Telekomünikasyon ekipmanları, bilgisayar kullanımı ve internetin yaygınlaşması ofislerdeki ve işletmelerdeki tüm yaşam alanlarında önemli değişimlere sebep olmuştur. Değişim beraberinde daha rekabetçi ve hızlı dönüşüm gösteren bir çevre yaratarak, işletmenin tüm görüntüsünde bir yenilik meydana getirmiştir (Wallace, 2004: 3). Bu kapsamda sanal dünya (cyberspace) işletmelere faydalanmak için eşsiz ve önemli bir ortam sağlamaktadır. Özellikle yeni bilgilerin yaratılması sürecinde örgütün önemli bir varlığını oluşturmaktadır. Ancak bu ortam iyi yönetilmediği takdirde bir takım sorunlarla karşılaşılması da kaçınılmaz olacaktır (Whitty ve Carr, 2006). Çünkü bilgi ve iletişim teknolojilerinin yanlış kullanımları büyüyen bir trendde seyretmekte ve bu da işletmeler için önemli bir problem olmaktadır (Wheatherbee, 2010). Bu problemlerin başında ise gittikçe daha fazla önem kazanan sanal kaytarma gelmektedir.

Sanal kaytarma kavramı uluslararası literatürde "cyberslacking" (Lavoie ve Pychyl, 2001; Blanchard ve Henle, 2008; İnce ve Gül, 2011), "cyberloafing" (Lim, 2002)ve "cyberbludging" (Mills vd., 2001)olarak kullanııırken, Türkiye'de yapılan çalışmalarda ise "sanal kaytarma" ve "siber aylaklık" "siber kaytarma" olarak adlandırılmıştır (Kaplan ve Öğüt, 2012: 591; Kalaycı, 2010; Köse vd., 2012; Özkalp vd., 2012; Kurt, 2011).Sanal kaytarma, iş saatlerinde iş dışı internet kullanımı, siber sapkınlık, işte kişisel internet kullanımı, internet suistimali, işyerinde eğlence amaçlı gezinme ve gereksiz bilgisayar kullanımı olarak da ifade edilmektedir (Vitak vd., 2011: 1751).Lim (2002: 675) sanal kaytarmayı, iş saatleri içerisinde işletme amaçları dışında web uygulamalarınınkullanılması olarak tanımlamıştır. Kim ve Byrne (2011)ve Restubog vd. (2011) ise, bu tanımlamalara sanal kaytarmanın kısmen de öz kontrol eksikliği ile ilgili olduğunu eklemiştir.

2.2. Sanal Kaytarmanın Yarattığı Fırsatlar ve Tehditler

Literatürde sanal kaytarmanın örgüt için zararları ve yararları konusunda iki farklı yaklaşım söz konusudur. Bazı araştırmacılar, sanal kaytarmanın işletmeler için son derece zararlı ve verimlilik kayıplarına neden olan bir olgu olduğunu söylerken, diğerleri ise sanal kaytarma sayesinde elde edilen eşsiz öğrenme fırsatlarına vurgu yapmaktadır.

İnternetin sunmuş olduğu eşsiz öğrenme olanakları, çalışanlara yeni bir bilgi ortamı sağlamakta ve böylece çalışanlar iş hayatı içerisinde daha yaratıcı ve değişimin hızında ilerleyen bireyler haline gelmektedir (Anandarajan vd., 2004; Block, 2001: 226; Greenfield ve Davis, 2002: 347; Stanton, 2002: 57; Blanchard ve Henle, 2008: 1069; Köse vd., 2012: 291). Çalışanların interneti kullanmaları, e-posta almaları ve göndermeleri iş ortamında yapılan genel iş aktivitelerinden birisi olarak değerlendirilebilir (Özkalp vd., 2012: 24). Anandarajan vd. (2004: 70-72) çalışanların internet üzerinden kişisel gruplara üye olarak, tartışma forumlarında yer alarak veya örgüt hakkında rekabetçi bilgiler edinilmesi amacıyla yaptıkları kaytarma davranışlarını öğrenmeyi artııcı sanal kaytarma davranışları olarak ifade etmiştir. Bu öğrenmeyi artırıcı uygulamalar yaratıcılığı, esnekliği, işbirliğini ve bir öğrenme çevresi oluşturarak (Blanchard ve Henle, 2008: 1069), genel olarak verimlilik üzerinde dolaylı bir etki yapmakta, rahatsızlıktan ziyade özgürlüğü destekleyen bir kültürün oluşumunu sağlamakta ve aynı zamanda çalışanları, üretken zihinsel ve sosyal çabalara teşvik etmektedir (Oravec, 2002: 61-62). Fakat bu davranışlar mevcut işletme amaçları içerisinde yapılması gereken davranışlar olarak yapılıyorsa, bu durumda bu davranışlar daha bilinçli ve iyi eğitimli çalışanlar nezdinde gerek niceliksel (performans artışı) gerekse de niteliksel olarak artarak verimlilik üzerinde doğrudan bir etki oluşturmaktadır (Anandarajan vd., 2004: 7072). Stanton (2002) tarafından yapılan araştırmada sık internet kullanan çalışanların daha az kullanan çalışanlara göre iş tutumları ve örgütsel konular açısından değerlendirilmiştir. İş tutumları açısından sık internet ve bilgisayar kullananların iş tatmini, duygusal bağlıık, destekleyici örgüt, çalışma ve gözetmen memnuniyeti ve promosyon fırsatları açısından yüksek puanlar aldığı gözlenmiştir. Örgütsel konular açısından ise, sık internet ve bilgisayar kullananların, otonomi, ilginç/zorlayıcı iş, çalışma arkadaşları 
ve yönetimin kalitesi, önemli sorumluluklar, organizasyonunu başarılı kabul etme ve iş-yaşam dengesi değişkenleri açısından yüksek puanlar aldığı gözlenmiştir (Stanton, 2002: 57). İnce ve Gül (2011: 520-522) tarafından yapılan araştırmada içsel kontrol odağına sahip olan çalışanların önemsiz sanal kaytarma davranışlarının, iş performansını artırdığı ve bu şekilde çalışanların işten ayrılma niyetlerinin azaldığı sonucuna ulaşılmıştır. Ancak bu faydaların bazıları işin tipine ve kişisel web kullanım süresine bağlıdır. Örneğin, Mahatanankoon ve Igbaria (2004) tarafından yapılan araştırmada, e-ticaret uygulamalarının iş tatmini ve performans (verimliliği artırdığı) sonucuna ulaşılmış, kişisel iletişim ve bilgi arayışı için kullanımların ise iş tatmini ve performans üzerinde bir etkisinin olmadığı saptanmıştır. Aslında çalışanların yoğun zihinsel çaba gerektiren veya diğer konulardaki işlerinden dolayı zaman zaman ortaya çıkan stresi azaltmak ve bir denge kurmak için internet ve bilgisayar aktivitelerinden faydalandıkları da söylenebilir (Ugrin vd., 2007; Lavoie ve Pychyl, 2001; Anandarajan vd., 2004: 71; Stanton, 2002: 57; Ovarec, 2001: 61; Block, 2001: 226). Çünkü bazı çalışanlar internet ve bilgisayarları bir ofis oyuncağı gibi görüp, bu oyuncak vasıtasıyla zihinlerini rahatlatıyor da olabilirler (Özkalp vd., 2012: 32). Bu açılardan bakıldığında sanal kaytarma, çalışanların özel telefon alma ve mesaj gönderme aktiviteleri gibi sıradan bir davranış olarak değerlendirilmektedir (Blanchard ve Henle, 2008: 1069).

Sunduğu bu olanakların yanında sanal kaytarmanın madalyonun iki yüzü gibi olduğu söylenebilir. Bir yüzü, sunduğu olanaklarla çalışanların iş yaşamına katkı yaptığını ifade ederken, diğer karanlık yüzü ise işletmelere önemli verimlilik kayıpları olduğunu ifade etmektedir. Bütün sanal kaytarma faaliyetlerinin aynı derecede zararlı olmadığı kabul edilse bile (Köse vd., 2011: 291), iş saatlerinde işverenin sunmuş olduğu internet ve bilgisayar olanaklarının iş dışı amaçlarla kullanılmasının ve iş zamanının işletme amaçları dışında harcanmasının, işletme verimliliği üzerinde negatif sonuçlar doğurabileceğini söylemek yanlış olmayacaktır. Çünkü bilgiye online erişim ve e-işletme, işletmelere önemli kolaylıklar sağlarken zamanla internet sessiz bir şekilde çalışanların iş saatleri içerisinde kendi mal ve hizmetlerini sattığı, müzik indirdiği, kumar oynadığı, gazete ve spor haberlerini takip ettiği, online oyunlar oynadığı, birbirlerine sürekli e-kartlar gönderdiği ve yetişkin sitelerinde (pornografik içerikli) ciddi zamanların harcandığı bir yer haline gelmiştir (Greengard, 2000; Whitty ve Carr, 2006: 237; Wheatherbee, 2010: 36; Ugrin vd., 2007; Greenfield ve Davis, 2002: 348).Öte yandan işletme içerisinde yapılması gereken işler kişisel amaçlı internet kullanımı nedeniyle yapılamadığından, yapılamayan işler iş dışı saatlerde online bağlanma yoluyla telafi edilmeye çalışılmaktadır (Richardson ve Benbunan-Fich, 2011: 157). Bu durum ise çalışanlarda önemli verimlilik kayıplarına neden olmaktadır. Güvenlik ihlalleri, telif hakkı problemleri, önceki ticaret sırlarının açıklanması, hakaret, ırksal taciz, boşa harcanan bilgisayar kaynakları, halkla ilişkilerde sorunlar, boşa harcanan yetenek, hukuki davalar ile karşı karşıya kalma (Flynn, 2001: 5-9; Eivazi, 2011) sanal kaytarmanın neden olduğu diğer kayıplar arasında gösterilebilir. Bu faaliyetler şirket kaynaklarını kullanmakta, üretkenlik kaybı yaratmakta ve işletmeleri yasal yükümlülükler altına sokmaktadır. Özelikle bazı işletmeler çalışanların internet tabanlı bu uygulamaları yüzünden cinsel istismarla bile suçlanmaktadır (Mills vd., 2001).

\subsection{Sanal Kaytarma Faaliyetlerinin Hukuki Boyutu}

Sanal kaytaran çalışanların (cyberslackers ya da cyberloafers) izlenmesi amacıyla işletme içerisinde çeşitli izleme sistemleri kurulmaya çalışılmıştır. Bu sistemler yardımıyla çalışanlar izlenmekte ve kaytarma yapan çalışanların tespit edilmesi sonucunda çalışanlar uyarı ya da iş akdinin fesih edilmesi sonucu ile karşı karşıya bırakılmıştır. Bu hususta Yargıtay tarafından alınan emsal kararlar, özellikle çalışanlar ve işverenler açısından önem arz etmektedir. Bu bağlamda, Yargıtay 9. Hukuk dairesi 2007/27583 esas, 2008/5294 karar ve 17.03.2008 tarihli kararında, «İşverenin açıça veya örtülü izni olmaksızın işyerinde internetin özel amaçlı olarak kullanımı yasaktır. Ancak bu yasak istisnaen acil durumlarda ve işine ilişkin sebeplerden dolayı meşru bir şekilde delinebilir. İşçinin, işverenin açıkça yasaklamasına rağmen interneti özel amaçlı kullanmasında önceden ihtara gerek olmaksızın iş sözleşmesi feshedilebileceği gibi; işçinin pornografik resimleri, videoları, işletmenin veri taşıyıcısına indirmesi ve yüklemesi halinde ihtara gerek yoktur." şeklinde bir karar alınmıştır (Web 1, 2012). Bu kararda internetin her bilgisayarda bir iz bıraktığı ve bu izin ise uzman üçüncü kişiler tarafından öğrenilerek işverenin kamuoyu nezdindeki şöhretine önemli ölçüde zarar verilebileceği göz önünde bulundurulmuştur. Ayrıca örtülü izin şartı için ise, altı ay boyunca işveren tarafından özel amaçlı kullanımın fark edilmesine rağmen ses çıkarılmaması gerekmektedir. Bu karar çalışanların işveren tarafından sunulan internet ve bilgisayarı açık veya örtülü izin almaksızın haber sitelerine girmek, e-posta göndermek-almak, oyun oynamak, yetişkin içerikli sitelere girmek gibi amaçlarla kullanamayacağını göstermektedir. Bu amaçlarla kullanıldığında ise iş akdinin 4857 sayılı İş Kanunu'nun 
25 II. maddesi uyarınca fesih sebebi doğmuş olmaktadır (Kaya, 2012). Yargıtay 9. Hukuk Dairesi 2009/447 esas, 2010/37516 karar ve 13.12.2010 tarihli kararında, 4857 sayılı İş Kanunu'nun 25 II-b maddesi uyarınca "Işverenin kendisine ait bilgisayar ve e-mail adresleri ile bu adreslere gelen e-postaları her zaman denetleme yetkisi bulunmaktadır." şeklinde bir karar alarak(Web 1, 2012), iş sözleşmesinin fesih edilmesi kararını kabul etmiştir. Illgili karara göre, işyerindeki bilgisayar ve internet hizmetinin çalışanlara işlerin etkin bir şekilde yerine getirmesi için sunulduğu, bu hizmetin bedelinin işveren tarafından karşılandığı ve bu nedenle de işverenin iş ile ilgili bu hizmetlerin kullanımı aşamasında tüm iş ve işlemlerin kontrol ve denetim hakkına sahip olduğu kabul edilmiştir. Bu nedenle işveren gerek işletmeye ait e-mail adresinden gerekse de özel olarak kullanılan e-mail adresi (hotmail, gmail, yahoo gibi) üzerinden yapılacak tüm işlemleri takip etme hakkına sahiptir(Kaya, 2012). Yargitay 9. Hukuk dairesi 2008/36305 esas, 2009/12393 karar ve 4.05.2009 tarihli kararında, «Davacının iş amaçlı bilgisayarı mesai saatleri içerisinde internet alış veriş ve oyun sitelerine birden fazla girmek sureti ile amacı dışında kullandığı ve bu süre zarfında zamanını iş görme edimine harcamadığı anlaşılmaktadır. Üstlenilen işin yetiştirilmesi veya işverenin zararının oluşmaması, bu olumsuz davranışı ortadan kaldırmaz. Davacı yan yükümlülüğünü ihlal etmiştir. Bu davranışının diğer işçi gibi işyerinde olumsuzluklara yol açtığı ve iş ilişkisinin işveren açısından devam ettirilmesinin beklenmez bir hal aldığı anlaşıımaktadır, işverenin iş sözleşmesini feshetmesi, davacının davranışlarından kaynaklanan nedene dayanmaktadır." şeklinde bir karar alınmıştır (Web 1, 2012). Bu karar ile çalışanın sadakat yükümlülüğünü ihlal ettiği ve işverenin varlıklarına zarar verdiği kabul edilmiştir. Ayrıca çalışanın uymakla yükümlü olduğu işyeri etik kurallarının 20. maddesindeki "bankaya ait varlıkların ve kaynakların verimsiz ve amaç dışı kullanılmayacağı" kuralııı ihlal edildiği ifade edilmiştir. Ayrıca bu kuralları yerine getirmeyen çalışanların, işlerini yetiştirmesinin veya işverene zarar vermemesinin de bu olumsuz davranışı ortadan kaldıramayacağını hükme bağlamıştır (Kaya, 2012; Web 2, 2012). Bu nedenle çalışanın yan yükümlülükleri ihlal ettiği gerekçesiyle, iş akdinin İş Kanunu'nun 25 II maddesi uyarınca feshi kabul edilmiştir.

Ortaya çıkan bu sonuçlara göre: iş sözleşmesi veya yan hükmü niteliğindeki iç yönetmeliklerin diğer bir anlatımla işyeri etik kurallarının ihlal edilmesi, fesih nedenini doğurmaktadır. Çünkü işverenler böyle bir durumda güven duygusunu yitirmekte ve haklı olarak fesih hakkını kullanmaktadır. Bu nedenle iş sözleşmesi ve diğer ek yükümlülüklerle internet ve bilgisayar kullanım politikalarının belirlenmesi, çalışan ve işveren açısından daha net ve yoruma açık olmayan bir uygulama olacaktır. Ayrıca 5237 sayılı Türk Ceza Kanunu>nun 136. maddesinde, «Kişisel verileri, hukuka aykırı olarak bir başkasına veren, yayan veya ele geçiren kişi, bir yıldan dört yıla kadar hapis cezası ile cezalandırılır.» hükmü yer almaktadır (TCK, 2004). Ceza Kanunu'na göre, işçinin bilgisi dışında elde edilen deliller hukuka aykırı olarak değerlendirilmekte ve bu yoldan delil elde etme girişiminde bulunanların cezalandırılacağı ifade edilmektedir. İşverenlerin Ceza Kanunu'na göre sorumlu duruma düşmemeleri için internet ve bilgisayar kullanım protokollerini belirlemelerinde ve bunları iş sözleşmesi ve diğer yan yükümlülükler içerisine aktarmalarında yarar vardır.

\subsection{Sanal Kaytarma Tipleri}

Lim (2002) sanal kaytarma tiplerini, işyerindeyken iş dışı amaçlarla sörf yapma faaliyetleri (sporla ilgili haber sitelerine girme, iş dışı doküman indirme gibi) ve e-mail faaliyetleri (e-mail kontrol etme, alma ve gönderme gibi) olmak üzere ikiye ayırmıştır. Anandarajan vd. (2004) çalışanların dört tür sanal kaytarma türü ile karşı karşıya kaldıklarını belirtmiştir. Bunlar; eğlence amaçılı (amaçsızca sörf yapma gibi), zarar verici (müzik indirme gibi), kişisel öğrenme (işletmeye faydalı makaleler indirme gibi) ve belirsiz (chat odalarında diğer işletmeler hakkında bilgi edinme gibi) sanal kaytarmadır. Mastrangelo vd. (2006) ise sanal kaytarma tiplerini üretken olmayan/üretkenlik karşıtı (online bankacilık işlemleri yapma gibi) ve zarar verici/ yıkıcı sanal kaytarma (yasadışı uygulamalarla meşgul olma gibi) olarak ikiye ayırmıştır. Blanchard ve Henle (2008) ise, sanal kaytarma faaliyetlerini önemsiz (iş dışı e-mail alma, haber sitelerini ziyaret etme gibi) ve önemli (yetişkin içerikli sitelere girme, kumar oynama sitelerini ziyaret etme gibi) sanal kaytarma olarak ikiye ayırmıştır. Önemsiz sanal kaytarma faaliyetinde bulunan çalışanlar bu kaytarmayı olağan bir durum olarak karşılamakta ve bu kaytarmanın işletme kaynaklarına zarar vermediğini düşünmektedirler. Önemli sanal kaytarma faaliyetinde ise çalışanlar kullandıkları sitelerin kendileri için ne kadar tehlikeli olduklarını ve bunun getireceği kanuni yükümlülükleri de bilmektedirler. Ancak buna rağmen kendilerini kaytarma eylemlerinden alamamaktadırlar. Bu sınıflandırma esasında Lim'in (2002) yaptığı araştırmayı daha da detaylandırmaktadır. 


\section{ARAŞTIRMA YÖNTEMI}

\subsection{Araştırmanın Amacı}

Internet gibi modern teknolojiler, çeşitli faydaların elde edilmesini sağladığı gibi bazı olumsuzlukları da beraberinde getirmektedir. Bu öneme binaen yapılan araştırmada, üniversite çalışanlarınınsanal kaytarma faaliyetlerinin sıklığının demografik değişkenler açısından farklılık gösterip göstermediğinin belirlenmesi ve bu kaytarma faaliyetleriarasındaki ilişkilerin incelenmesi amaçlanmaktadır.

\subsection{Veri Toplama Araç ve Teknikleri}

Çalışanların önemli ve önemsiz sanal kaytarma faaliyetlerini kullanma sıklığının belirlenmesi amacıyla anket yöntemi kullanılmıştır. Araştırma anketi, sanal kaytarma faaliyetlerini ifade eden 19 soru ve demografik bilgileri içeren 7 sorudan oluşmaktadır. Sanal kaytarma faaliyetlerine ilişkin 19 soruya ait verilerin faktör analizine uygun olup olmadığı kontrol etmek için, öncelikle faktör analizi yapılmıştır. Ancak yapılan faktör analizi sonucunda, faktör yük değerleri düşük olan $(<0,50) 4$ soru analizden çıkarılmıştır. Ayrıca faktör yapısını bozan 1 soru kapsam dışı bırakılmıştır. Faktör analizi sonucunda beşli likert ( $1=$ hiçbir zaman, $5=$ her zaman) tipi 14 soruya ait KMO örneklem uygunluğu test sonucu 0,885 olarak bulunmuş, Barlett test sonucu da anlamlı çıkmıştır $(p<0,05)$. KMO değerinin 0,80 'den büyük olması, verilerin faktör analizi için yüksek/iyi derecede uygun olduğunu göstermektedir (Altunışık vd., 2010: 266; Çokluk vd., 2012: 207). Faktör analizi sonucunda açıklanan toplam varyans (özdeğerleri 1 veya daha fazla olan faktörlerin alınması kriterine göre) $54.06 \%$ olarak bulunmuştur. Açıklanan toplam varyansın $28,60 \%$ 'lık kısmını önemli sanal kaytarma faktörü, 25,46\%'lık kısmını ise önemsiz sa- nal kaytarma faktörü oluşturmaktadır. Açıklanan toplam varyans için bulunan oran, bir modelin makul olarak kabul edilebilmesi için yeterli bir orandır (Habing, 2005: 4; Altunışık vd., 2010: 273). Ayrıca ilgili sorulara yönelik güvenilirlik analizi yapılmış ve Cronbach's Alpha değeri 0,888 olarak tespit edilmiştir. Cronbach's Alpha değeri, önemli sanal kaytarma faaliyetleri için 0,850 ve önemsiz sanal kaytarma faaliyetleri için ise $0,853^{\prime}$ tür. Bu değer anket uygulaması sonucu elde edilen verilerin yüksek derecede güvenilir olduğunu göstermektedir.

Anket formunda yer alan $1,3,7,10,11$ numaralı sorularda, Blanchard ve Henle'nin (2008) "Correlates of Different Forms of Cyberloafing: The Role of Norms and External Locus of Control" adlı çalışmasından faydalanılmıştır. 12, 13, 14 numaralı sorularda, Lim'in (2002) "The IT Way of Loafing on the Job: Cyberloafing, Neutralizing and Organizational Justice" adlı çalışmasından faydalanılmıştır. 4, 5, 6, 8, 9 numaralı sorularda, Özkalp vd. (2012) tarafından yapılan "Sapkın Örgütsel Davranışlar ve Çalışma Yaşamında Yeni Bir Olgu: Sanal Kaytarma (Cyberloafing) ve İş iliş̧kilerine Etkileri" adlı çalışmadan faydalanıımıştır. 2 numaralı soru ise araştırmacılar tarafından veri toplama araclna dâhil edilmiştir. 1-8 numaralı sorular önemli sanal kaytarma faaliyetlerini ifade ederken, 9-14 numaralı sorular ise önemsiz sanal kaytarma faaliyetlerini ifade etmektedir. Tablo 1'deki verilerden faydalanıldığında, çalışanların "önemsiz sanal kaytarma faaliyetlerine ( $\bar{X}=3.17)$ " orta derecede, "önemli sanal kaytarma faaliyetlerine $(\bar{X}=2.12)^{\prime \prime}$ ise düşük derecede katıldıkları gözlenmektedir. İlgili sorulara ve faktörlere ait detaylı tanımlayıcı istatistikler Tablo 1'de sunulmuştur. 


\begin{tabular}{|c|c|c|c|c|c|c|c|c|c|c|c|c|c|c|c|}
\hline 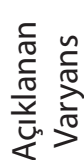 & \multicolumn{8}{|c|}{$\begin{array}{l}8 \\
\stackrel{0}{0} \\
\stackrel{\infty}{0}\end{array}$} & \multicolumn{6}{|c|}{$\begin{array}{l}\bar{\sigma} \\
\stackrel{+}{v}\end{array}$} & \multirow[t]{2}{*}{$\begin{array}{l}\overline{8} \\
0 \\
\dot{4}\end{array}$} \\
\hline 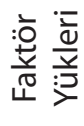 & $\stackrel{m}{\stackrel{m}{o}}$ & $\stackrel{m}{\frac{n}{0}}$ & $\frac{N}{0}$ & 悉 & ô. & $\begin{array}{l}0 \\
0 \\
0\end{array}$ & 㸃 & $\begin{array}{l}\hat{n} \\
\hat{\alpha} \\
0\end{array}$ & $\begin{array}{l}\tilde{n}^{0} \\
0 \\
0\end{array}$ & $\frac{+}{\stackrel{N}{0}}$ & \begin{tabular}{l}
\multirow{N}{*}{} \\
$\tilde{0}$
\end{tabular} & $\stackrel{m}{\hat{\sigma}}$ & 종 & : & \\
\hline 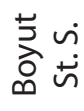 & \multicolumn{8}{|c|}{$\stackrel{\hat{N}}{0}$} & \multicolumn{6}{|c|}{ ઠू } & \\
\hline 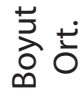 & \multicolumn{8}{|c|}{$\stackrel{\stackrel{N}{N}}{\frac{1}{N}}$} & \multicolumn{6}{|c|}{$\frac{\bar{m}}{\bar{m}}$} & \\
\hline 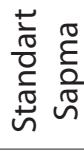 & $\stackrel{8}{-}$ & $\stackrel{\text { ㅁ }}{-}$ & $\stackrel{0}{-}$ & $\stackrel{\stackrel{\rho}{m}}{=}$ & $\stackrel{\overbrace{}}{=}$ & $\underset{-}{-}$ & $\cong$ & @ & $\stackrel{\stackrel{\circ}{2}}{-}$ & $\stackrel{\circ}{\circ}$ & $\stackrel{m}{=}$ & $\stackrel{\stackrel{\rho}{m}}{\sim}$ & $\stackrel{⿱ 亠 士}{-}$ & $\stackrel{\bar{m}}{-}$ & \\
\hline 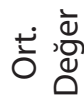 & ò & $\stackrel{\circ}{i}$ & $\underset{i}{\stackrel{0}{*}}$ & $\begin{array}{l}\infty \\
\stackrel{\infty}{\sim} \\
\stackrel{1}{*}\end{array}$ & 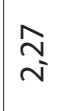 & $\stackrel{\cong}{=}$ & & $\stackrel{\stackrel{\rho}{n}}{-}$ & 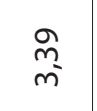 & $\begin{array}{l}m \\
\infty \\
m \\
m\end{array}$ & 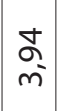 & \begin{tabular}{l}
\multirow{0}{0}{} \\
i
\end{tabular} & ò & $\frac{0}{i}$ & \\
\hline$\subseteq$ & in & in & in & เก & 뜨 & in & โก & 六 & $\underline{\underline{n}}$ & & 드 & 드 & 드 & 드 & \\
\hline 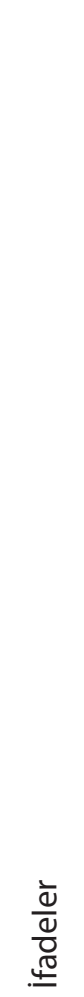 & 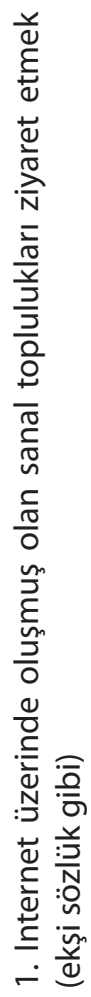 & 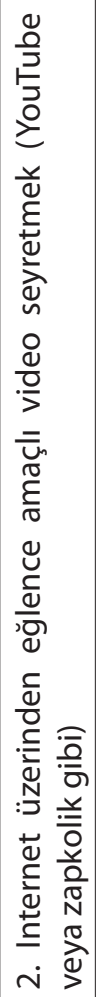 & 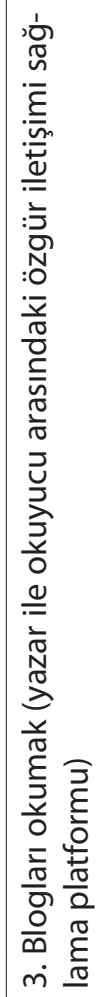 & 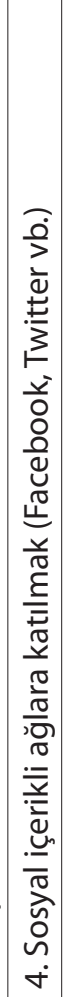 & 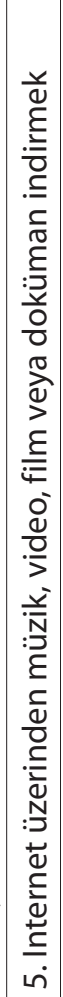 & 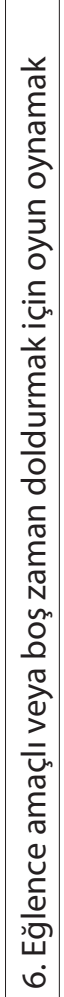 & 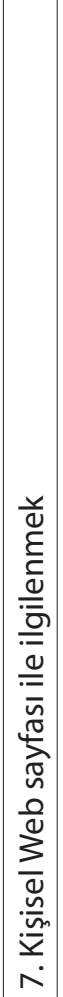 & 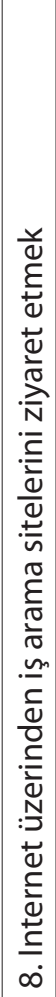 & 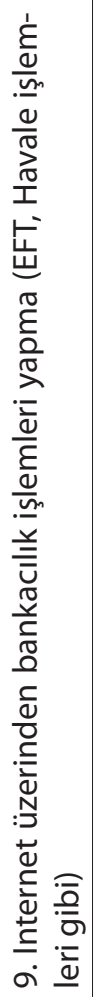 & 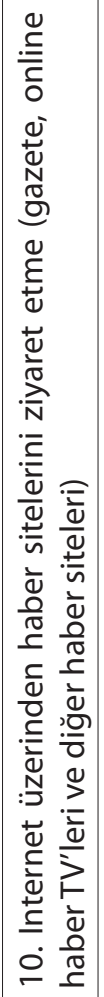 & 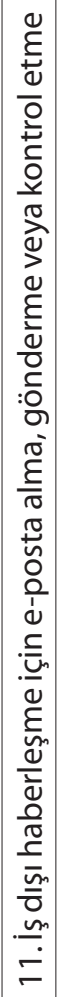 & 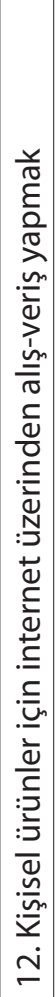 & 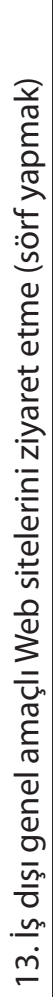 & 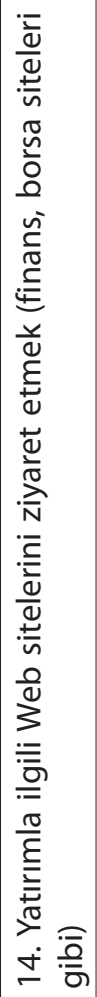 & \multirow[b]{2}{*}{$\frac{\frac{\pi}{2}}{\frac{\pi}{4}}$} \\
\hline 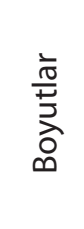 & \multicolumn{8}{|c|}{ 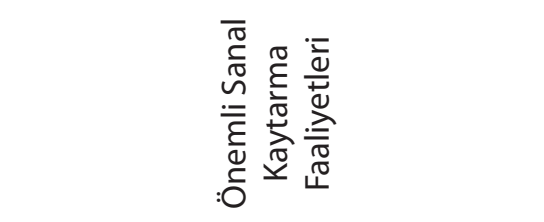 } & \multicolumn{6}{|c|}{ 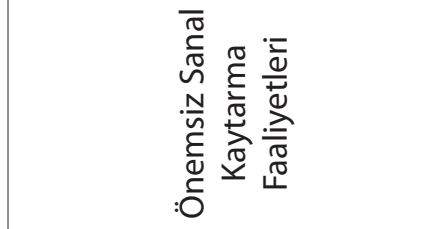 } & \\
\hline
\end{tabular}




\subsection{Araştırmanın Evreni ve Örneklem Seçimi}

Araştırmanın evrenini Balıkesir Üniversitesi'nin 1451 akademik ve idari personeli oluşturmaktadır (MYPP, 2012: 31-33). Bu çerçevede $p$ ve $q$ değerleri 0.5 ve 0.5 , hoşgörü miktarı $E=0.05$ ve $\% 95$ güven aralığında 1.451 kişiyi 304 kişinin temsil etme yeteneğine sahip olduğu hesaplanmıştır (Altunışık vd., 2010: 135). Anket, basit rastgele örnekleme yöntemi ile araştırmacılar tarafından bizzat ulaşılarak uygulanmıştır. Gerçekleştirilen anket uygulaması sonucunda geri dönen anket sayısı 151'dir. Geri dönüş oranı yaklaşık olarak $\% 50$ 'dir. Bu sonuç, örneklemin evrenin yaklaşık olarak yarısını temsil edebildiğini göstermektedir.

\subsection{Araştırma Hipotezleri}

Genel tarama metodu ile hazırlanan bu çalışmada belirlenen başlıca hipotezler şunlardır:

$\mathrm{H}_{1}$ : Çalışanların önemli ve önemsiz sanal kaytarma faaliyetlerinde bulunma sıklığı demografik değişkenlere (cinsiyet, medeni durum, statü, yaş, eğitim durumu, aylık gelir ve iş dışı internet ve bilgisayar kullanım süresi) göre farklılık göstermektedir.

Morahan-Martin (1998) tarafından yapılan araştırmada erkeklerin büyük oranda internet kullanıcısı olduğu ve bu durumun da esasında bilgisayar kültürünün maskülinasyonundan (erkek bilim adamları, matematikçiler ve hackerler tarafından geliştirilmesi) kaynaklandığı tespit edilmiştir. Ancak bu durum neticede patolojik internet kullanımını tetikleyen bir değişken olarak cinsiyet faktörünü ortaya çıkarmıştır. Garrett ve Dangizer (2008) ve Vitak vd. (2011) tarafından yapılan araştırmada da erkek çalışanların daha sık sanal kaytarma yaptığı saptanmıştır. Matanda vd. (2004) tarafından yapılan araştırmada erkeklerin eğlence için interneti kullandıkları ve erkeklerin kadınlardan daha fazla ticari amaçlar için interneti kullandıkları sonucuna ulaşıımıştır. Özkalp vd. (2012) tarafından yapılan araştırmada ise, kadınların erkeklerden daha fazla yazılı görüşme (chat) yaptıkları sonucuna ulaşılmıştır. Bu bağlamda cinsiyet değişkeni açısından aşağıdaki hipotez ileri sürülmüştür:

$\mathrm{H}_{1}$ : Çalışanların önemli ve önemsiz sanal kaytarma faaliyetlerinde bulunma sıklığı cinsiyet değişkenine göre farklılık göstermektedir.

Çalışanların bekâr veya evli olmaları internet ve bilgisayar kullanma alışkanlıklarında da değişiklik yaratmaktadır. Evli olan bireylerin kendilerine yüklemiş oldukları sorumluluklar yaşamsal anlamda da farklı beklentiler oluşturmalarına neden olmaktadır. Bekâr çalışanların yaşamsal anlamda daha farklı ve daha geniş zamana sahip olmaları ihtiyaçlarını da çeşitlendirmektedir (Özkalp vd.,
2012: 27). Internet ve bilgisayar teknolojisinin de bu intiyaçları sağlayabilecek etkili bir araç olması, medeni durum açısından bekâr ve evliler arasında anlamlı farklılıklar yaratabilmektedir. Bu bağlamda medeni durum değişkeni açısından aşağıdaki hipotez ileri sürülmüştür:

$H_{16}$ : Çalışanların önemli ve önemsiz sanal kaytarma faaliyetlerinde bulunma sıklığı medeni durum değişkenine göre farklılık göstermektedir.

Ugrin vd. (2007) ve Garrett ve Dangizer (2008) tarafından yapılan araştırmalarda da mesleki statü sanal kaytarmanın anlamlı değişkeni olarak belirlenmiştir. Araştırma sonucunda sanal kaytarma düşük statüdeki personel ile ilgili çıkmazken; daha çok yönetim, Ar-Ge, personel gibi bölümlerdeki yüksek statüde çalışanlarla ilişkili olarak çıkmıştır.Köse vd. (2012) tarafından yapılan araştırmada da akademik personelin (araştırma görevlisi) çeşitli amaçlarla sanal kaytarma yaptıkları belirlenmiştir. Özkalp vd. (2012) tarafından yapılan araştırmada, akademik personelin genel amaçlı dolaşma hariç, diğer kaytarma davranışlarını daha fazla yaptıkları belirlenmiştir. Bu bağlamda statü değişkeni açısından aşağıdaki hipotez ileri sürülmüştür:

$\mathrm{H}_{1}$ : Çalışanların önemli ve önemsiz sanal kaytarma faaliyetlerinde bulunma sıklığı statü değişkenine göre farklılık göstermektedir.

Mastrangelo vd. (2006) tarafından yapılan araştırmada daha genç çalışanların yıkıcı/önemli sanal kaytarma eğilimlerinin daha fazla olduğu saptanmıştır. Phillips ve Reddie (2007) tarafından yapılan araştırmada genç çalışanların iş yerinde daha fazla iş dışı e-mail kullanımı oranına sahip olduğu gözlenmiştir. Vitak vd. (2011), Ugrin vd. (2007) ve Köse vd. (2012) tarafından yapılan araştırmalarda genç çalışanlar ile sanal kaytarma sıklığı ve çeşitliliği arasında pozitif anlamlı bir farklııık saptanmıştır. Atkin vd. (1998: 484) tarafından yapılan araştırmada yaşın küçülmesi ile internet teknolojisine uyum arasında ilişki bulunmuştur. Kraut vd. (1998) tarafından yapılan araştırmada yaşın büyümesi ile internet kullanımı arasında negatif bir ilişki bulunmuştur. Matanda vd. (2004) tarafından yapılan araştırmada genç olanların eğlence için interneti kullandıkları sonucuna ulaşılmıştır. Bu bağlamda yaş değişkeni açısından aşağıdaki hipotez ileri sürülmüştür:

$\mathrm{H}_{1 \mathrm{~d}}$ : Çalışanların önemli ve önemsiz sanal kaytarma faaliyetlerinde bulunma sıklığı yaş değişkenine göre farklılık göstermektedir.

Eğitim düzeyi yüksek çalışanların iş yerinde daha fazla iş dışı e-mail kullanımı oranına sahip olduğu gözlenmiştir (Phillips ve Reddie, 2007).Matanda vd. (2004) 
tarafından yapılan araştırmada eğitim düzeyi yüksek kişilerin iletişim için internet kullanım oranlarının daha fazla olduğu sonucuna ulaşılmıştır. Özkalp vd. (2012) tarafından yapılan araştırmada, çeşitli önemsiz ve önemli sanal kaytarma davranışlarının eğitim düzeyi yüksek kişilerce daha fazla yapıldığı sonucuna ulaşılmıştır. Atkin vd. (1998: 484) tarafından yapılan araştırmada eğitim seviyesinin yüksek olması ile internet uyumu arasında ilişki bulunmuştur. Garrett ve Dangizer (2008) tarafından yapılan araştırma sonucunda sanal kaytarma, Ar-Ge, personel gibi bölümlerdeki eğitim düzeyi yüksek çalışanlarda daha yüksek görülmüştür. Bu bağlamda eğitim durumu değişkeni açısından aşağıdaki hipotez ileri sürülmüştür:

$\mathrm{H}_{11}$ : Çalışanların önemli ve önemsiz sanal kaytarma faaliyetlerinde bulunma sıklığı eğitim durumu değişkenine göre farklılık göstermektedir.

Garrett ve Dangizer (2008) tarafından yapılan araştırmada gelirsanal kaytarmanın anlamlı değişkeni olarak belirlenmiştir. Çalışanların gelir kaynaklarının artması, tüketim ve yaşam alışkanlıklarının değişmesine katkı sağlamaktadır. Bilgisayar ve iletişim teknolojilerinin gelişmesi de bu değişime hizmet eden önemli bir araç olarak ortaya çıkmaktadır. Bu bağlamda aylık gelir değişkeni açııından aşağıdaki hipotez ileri sürülmüştür:

$\mathrm{H}_{1 f}$ : Çalışanların önemli ve önemsiz sanal kaytarma faaliyetlerinde bulunma sıklığı aylık gelir değişkenine göre farklılık göstermektedir.

İş içerisinde sürekli bilgisayar kullanan çalışanlardaha sık sanal kaytarma faaliyetlerinde bulunmaktadırlar (Vitak vd., 2011). Mastrangelo vd. (2006) tarafından yapılan araştırmada da daha uzun süre internet erişimi olan çalışanların yıkıcı/önemli sanal kaytarma faaliyetlerinde bulunma sıklığının daha fazla olduğu saptanmıştır. Çalışanların işlerinin bir parçası olarak sürekli bilgisayar kullanmaları ve uzun süreli internet olanaklarına sahip olması, çalışanların iş saatlerinde sanal kaytarma yapabilmelerini etkilediği gibi sanal kaytarma faaliyetlerinde bulunma süresini de etkileyebilmektedir. Ayrıca bu süredeki değişim, sanal kaytarma faaliyetlerinin türlerinde de bir değiş̧im ya- ratabilmektedir. Bu bağlamda günlük iş saatlerinde iş dışı internet ve bilgisayar kullanma süresi değişkeni açısından aşağıdaki hipotez ileri sürülmüştür:

$\mathrm{H}_{19}$ : Çalışanların önemli ve önemsiz sanal kaytarma faaliyetlerinde bulunmaları, iş saatlerinde iş dışı internet ve bilgisayar kullanma süresindeki (süre/ günlük) değişime göre farklılık göstermektedir.

Mastrangelo vd. (2006) tarafından yapılan araştırmada yıkıcı/önemli sanal kaytarma faaliyetlerinde bulunanların üretkenlik karşıtı/önemsiz sanal kaytarma faaliyetlerinde de bulundukları saptanmıştır. Çalışanların önemsiz sanal kaytarma faaliyetlerine göz yumulması veya gerekli tedbirlerin alınmaması, önemli sanal kaytarma faaliyetlerinde de bulunulması için çalışanlara güç vermektedir. Bu bağlamda önemli ve önemsiz sanal kaytarma faaliyetleri arasındaki ilişki açısından aşağıdaki hipotez ileri sürülmüştür:

$\mathrm{H}_{2}$ : Önemsiz sanal kaytarma faaliyetleri ile önemli sanal kaytarma faaliyetleriarasında pozitif bir ilişki vardır.

\subsection{Araştırmanın Yöntemi}

Verilerin normal dağılması nedeniyle parametrik testlerden faydalanılmıştır. Önemli ve önemsiz sanal kaytarma faaliyetleri ile çalışanların cinsiyet, medeni durum ve statü değişkenleri arasındaki görüş farklıııIarını tespit etmek amacıyla bağımsız örneklem t-testi kullanılmıştır. Önemli ve önemsiz sanal kaytarma faaliyetlerinin yaş, eğitim durumu, aylık gelir ve iş saatlerinde iş dışı internet ve bilgisayar kullanım süresi değişkenlerine göre farklılık gösterip göstermediğini analiz etmek için tek yönlü varyans analizinden (one-way ANOVA) yararlanılmıştır. Önemli ve önemsiz sanal kaytarma faaliyetleri arasındaki ilişkileri ve bu ilişkilerin yönünü tespit etmek amacıyla Pearson korelasyon analizi yapılmıştır. 


\section{BULGULAR}

\subsection{Demografik Veriler}

Demografik değişkenlerin frekans ve yüzdelerine ait veriler Tablo 2 ' de sunulmuştur.

Tablo 2:Demografik Değişkenler Tablosu

\begin{tabular}{|c|c|c|c|c|c|c|c|}
\hline Değişkenler & Alt Değişkenler & Frekans & $\%$ & Değişkenler & Alt Değişkenler & Frekans & $\%$ \\
\hline \multirow{2}{*}{ Cinsiyet } & Erkek & 89 & 58,9 & \multirow{2}{*}{ Medeni Durum } & Bekâr & 40 & 26,5 \\
\hline & Kadın & 62 & 41,1 & & Evli & 111 & 73,5 \\
\hline \multirow{4}{*}{$\begin{array}{l}\text { Eğitim } \\
\text { Durumu }\end{array}$} & $\begin{array}{l}\text { Yüksekokul ve } \\
\text { altı }\end{array}$ & 23 & 15,2 & \multirow{4}{*}{ Aylık Gelir } & 1500 TL den az & 19 & 12,6 \\
\hline & Lisans & 37 & 24,5 & & $1501-2500$ & 75 & 49,7 \\
\hline & Yüksek Lisans & 30 & 19,9 & & $2501-3500$ & 45 & 29,8 \\
\hline & Doktora & 61 & 40,4 & & 3501 ve üstü & 12 & 7,9 \\
\hline \multirow{6}{*}{$\begin{array}{c}\text { İş dışı } \\
\text { Günlük } \\
\text { Ortalama } \\
\text { Internet ve } \\
\text { Bilgisayar } \\
\text { Kullanımı }\end{array}$} & 30 dakikadan az & 54 & 35,8 & \multirow{4}{*}{ Yaş } & 25 yaş ve altı & 14 & 9,3 \\
\hline & 30-60 dk. arası & 45 & 29,8 & & 26-35 yaş & 50 & 33,1 \\
\hline & 1-3 saat arası & 35 & 23,2 & & $36-45$ yaş & 66 & 43,7 \\
\hline & $\begin{array}{l}3 \text { ve daha fazla } \\
\text { saat }\end{array}$ & 12 & 7,9 & & 46 ve üstü yaş & 21 & 13,9 \\
\hline & $\begin{array}{l}\text { İnternet } \\
\text { kullanmayan }\end{array}$ & 5 & 3,3 & \multirow{2}{*}{ Statü } & Akademik personel & 110 & 72,8 \\
\hline & & & & & İdari personel & 41 & 27,2 \\
\hline & TOPLAM & 151 & 100 & & TOPLAM & 151 & 100 \\
\hline
\end{tabular}

\subsection{Hipotezlerin Testi}

$\mathrm{H}_{1 \mathrm{a}}$ hipotezini test etmek amacıyla bağımsız örneklem t-testinden faydalanılmıştır. Analiz sonucunda, çalışanların önemli ve önemsiz sanal kaytarma faaliyetlerine ilişkin ifadelere katılma derecesi cinsiyet değişkenine göre istatistiksel açıdan anlamlı bir farklılık saptanmamıştır ( $p>0,05)$. Anlamlı çıkmayan analiz sonucu yer kısıtı nedeniyle tablo halinde gösterilmemiştir. $\mathrm{H}_{12}$ hipotezi \%95 güven aralığında önemli ve önemsiz sanal kaytarma $(p>0,05)$ boyutları açısından desteklenmemiştir.

$H_{1 b}$ hipotezini test etmek amacıyla bağımsız örneklem t-testinden faydalanılmıştır. Analiz verileri
Tablo 3'de gösterilmektedir. Analiz sonucunda, medeni durum ile önemli sanal kaytarma faaliyetleri arasında istatistiksel açıdan anlamlı derecede bir farklılık saptanmıştır. Çalışanların önemli sanal kaytarma faaliyetleri ile ilgili sorulara verdikleri yanıtların aritmetik ortalamaları incelendiğinde, genel olarak bekâr olanların evli olanlara göre daha yüksek derecede önemli sanal kaytarma faaliyetlerinde bulunduğu şeklinde yorumlanabilir. $\mathrm{H}_{1 \mathrm{~b}}$ hipotezi $\% 95$ güven aralığında önemli sanal kaytarma boyutu $(p=0,001)$ açısından desteklenirken, önemsiz sanal kaytarma $(p=0,796)$ boyutu açısından desteklenmemiştir.

Tablo 3:Medeni Duruma İlişkin Bağımsız Örneklem t-Testi Tablosu

\begin{tabular}{|l|l|c|c|c|c|c|}
\hline Sanal Kaytarma Boyutları & Kurum & Kişi & Ortalama & $\begin{array}{c}\text { Std. } \\
\text { Sapma }\end{array}$ & Ser. Der. & $\begin{array}{c}\text { P değeri } \\
\text { (Sig.) }\end{array}$ \\
\hline \multirow{2}{*}{ Önemsiz Sanal Kaytarma } & Bekâr & 40 & 3,20 & 0,90 & 149 & 0,796 \\
\cline { 2 - 6 } & Evli & 111 & 3,16 & 0,96 & & \\
\hline \multirow{2}{*}{ Önemli Sanal Kaytarma } & Bekâr & 40 & 2,54 & 0,93 & \multirow{2}{*}{149} & \multirow{2}{*}{$0,001^{*}$} \\
\cline { 2 - 5 } & Evli & 111 & 1,97 & 0,65 & & \\
\hline
\end{tabular}

( Not:* $p<0,05$ )

$\mathrm{H}$ hipotezini test etmek amacıyla bağımsız örneklem ${ }^{1 c}$ t-testinden faydalanılmıştır. Analiz verileri Tablo 4'de gösterilmektedir.Analiz sonucunda, statü ile önemli ve önemsiz sanal kaytarma faaliyetleri arasında istatistiksel açıdan anlamlı derecede bir farklılık saptanmıştır. Çalışanların önemli ve önemsiz sanal 
kaytarma faaliyetleri ile ilgili sorulara verdikleri yanıtların aritmetik ortalamaları incelendiğinde, genel olarak akademik personelin idari personele göre daha yüksek derecede önemli ve önemsiz sanal kaytarma faaliyetlerinde bulunduğu şeklinde yorumlanabilir.
$\mathrm{H}_{1 c}$ hipotezi \%95 güven aralığında önemli sanal kaytarma boyutu $(p=0,008)$ ve önemsiz sanal kaytarma $(p=0,000)$ boyutu açısından desteklenmiştir.

Tablo 4: Statü Değişkenine İlişkin Bağımsız Örneklem t-Testi Tablosu

\begin{tabular}{|l|l|c|c|c|c|c|}
\hline $\begin{array}{l}\text { Sanal Kaytarma } \\
\text { Boyutları }\end{array}$ & \multicolumn{1}{|c|}{ Statü } & Kişi & Ortalama & $\begin{array}{c}\text { Std. } \\
\text { Sapma }\end{array}$ & Ser. Der. & $\begin{array}{c}\text { P değeri } \\
\text { (Sig.) }\end{array}$ \\
\hline \multirow{2}{*}{$\begin{array}{l}\text { Önemsiz Sanal } \\
\text { Kaytarma }\end{array}$} & Akademik personel & 110 & 3,37 & 0,90 & 149 & $0,000^{*}$ \\
\cline { 2 - 6 } & İdari personel & 41 & 2,65 & 0,96 & & \\
\hline \multirow{2}{*}{$\begin{array}{l}\text { Önemli Sanal } \\
\text { Kaytarma }\end{array}$} & Akademik personel & 110 & 2,22 & 0,93 & 149 & \multirow{2}{*}{$0,008^{*}$} \\
\cline { 2 - 5 } & İdari personel & 41 & 1,85 & 0,65 & & \\
\hline
\end{tabular}

( Not: $\left.{ }^{*}<0,05\right)$

$\mathrm{H}_{1 \mathrm{~d}}$ hipotezini test etmek amacıyla tek yönlü varyans analizinden faydalanılmıştır. Analiz verileri Tablo 5'de gösterilmektedir. Analiz sonucunda, yaş ile önemli ve önemsiz sanal kaytarma faaliyetleri arasında istatistiksel açıdan anlamlı derecede bir farklılık saptanmıştır. Çalışanların önemli ve önemsiz sanal kaytarma faaliyetleri ile ilgili sorulara verdikleri ya- nıtların aritmetik ortalamaları incelendiğinde genel olarak genç çalışanların daha fazla önemli ve önemsiz sanal kaytarma faaliyetlerinde bulunduğu şeklinde yorumlanabilir. $\mathrm{H}_{1 \mathrm{~d}}$ hipotezi \%95 güven aralığında önemli sanal kaytarma boyutu $(p=0,000)$ ve önemsiz sanal kaytarma $(p=0,024)$ boyutu açısından desteklenmiştir.

Tablo 5:Yaş Değişkenine İlişkin Tek Yönlü Varyans Analizi Tablosu

\begin{tabular}{|l|l|c|c|c|c|c|}
\hline \multicolumn{2}{|c|}{ Sanal Kaytarma Boyutları } & $\begin{array}{c}\text { Kareler } \\
\text { Toplamı }\end{array}$ & $\begin{array}{c}\text { Serbestlik } \\
\text { Derecesi }\end{array}$ & $\begin{array}{c}\text { Kareler } \\
\text { Ort. }\end{array}$ & F & $\begin{array}{c}\text { P değeri } \\
\text { (Sig.) }\end{array}$ \\
\hline \multirow{3}{*}{$\begin{array}{l}\text { Önemsiz Sanal } \\
\text { Kaytarma }\end{array}$} & Gruplararası & 8,217 & 3 & 2,739 & \multirow{2}{*}{3,231} & \multirow{2}{*}{$0,024^{*}$} \\
\cline { 2 - 5 } & Gruplariçi & 124,614 & 147 & 0,848 & & \\
\cline { 2 - 6 } & Toplam & 132,830 & 150 & & & \multirow{2}{*}{$0,000^{*}$} \\
\hline \multirow{3}{*}{$\begin{array}{l}\text { Önemli Sanal } \\
\text { Kaytarma }\end{array}$} & Gruplararası & 20,525 & 3 & 6,842 & 14,572 & \\
\cline { 2 - 5 } & Gruplariçi & 69,017 & 147 & 0,470 & & \\
\cline { 2 - 5 } & Toplam & 89,542 & 150 & & & \\
\hline
\end{tabular}

( Not: $\left.{ }^{*} \mathrm{p}<0,05\right)$

$\mathrm{H}_{1 \text { e }}$ hipotezini test etmek amacıyla tek yönlü varyans analizinden faydalanılmıştır. Analiz verileri Tablo 6'da gösterilmektedir. Analiz sonucunda, eğitim durumu ile önemli ve önemsiz sanal kaytarma faaliyetleri arasında istatistiksel açıdan anlamlı derecede bir farklılık saptanmıştır. Çalışanların önemsiz sanal kaytarma faaliyetleri ile ilgili sorulara verdikleri yanıtların aritmetik ortalamaları incelendiğinde, genel olarak eğitim düzeyi yüksek çalışanların daha fazla önemsiz sanal kaytarma faaliyetlerinde bulunduğu şeklinde yorumlanabilir. Çalışanların önemli sanal kaytarma fa- aliyetleri ile ilgili sorulara verdikleri yanıtların aritmetik ortalamaları incelendiğinde ise, genel olarak lisans mezunlarının (önemli birbölümü öğretim görevlileri, araştırma görevlileri ve uzmanlardan oluşmakta) diğer eğitim düzeylerine göre daha fazla önemli sanal kaytarma faaliyetlerinde bulunduğu şeklinde yorumlanabilir. $\mathrm{H}_{1 \mathrm{e}}$ hipotezi \%95 güven aralığında önemli sanal kaytarma boyutu $(p=0,000)$ ve önemsiz sanal kaytarma ( $p=0,000)$ boyutu açısından desteklenmiştir. 
Tablo 6: Eğitim Durumuna İlişkin Tek Yönlü Varyans Analizi Tablosu

\begin{tabular}{|c|c|c|c|c|c|c|}
\hline \multicolumn{2}{|c|}{ Sanal Kaytarma Boyutları } & $\begin{array}{l}\text { Kareler } \\
\text { Toplamı }\end{array}$ & $\begin{array}{c}\text { Serbestlik } \\
\text { Derecesi }\end{array}$ & $\begin{array}{c}\text { Kareler } \\
\text { Ort. }\end{array}$ & $\mathrm{F}$ & $\begin{array}{l}\text { P değeri } \\
\text { (Sig) }\end{array}$ \\
\hline \multirow{3}{*}{$\begin{array}{l}\text { Önemsiz } \\
\text { Sanal } \\
\text { Kaytarma }\end{array}$} & Gruplararası & 29,672 & 3 & 9,891 & \multirow[t]{3}{*}{14,094} & \multirow[t]{3}{*}{$0,000^{*}$} \\
\hline & Gruplariçi & 103,158 & 147 & 0,702 & & \\
\hline & Toplam & 132,830 & 150 & & & \\
\hline \multirow{3}{*}{$\begin{array}{l}\text { Önemli Sanal } \\
\text { Kaytarma }\end{array}$} & Gruplararası & 12,666 & 3 & 4,222 & \multirow[t]{3}{*}{8,073} & \multirow[t]{3}{*}{$0,000^{*}$} \\
\hline & Gruplariçi & 76,876 & 147 & 0,523 & & \\
\hline & Toplam & 89,542 & 150 & & & \\
\hline
\end{tabular}

( Not: ${ }^{*} p<0,05$ )

$\mathrm{H}$ hipotezini test etmek amaciyla tek yönlü varyâns analizinden faydalanılmıştır. Analiz verileri Tablo 7'de gösterilmektedir. Analiz sonucunda, aylık gelir durumu ile önemli ve önemsiz sanal kaytarma faaliyetleri arasında istatistiksel açıdan anlamlı derecede bir farklılık saptanmıştır. Çalışanların önemli sanal kaytarma faaliyetleri ile ilgili sorulara verdikleri yanıtların aritmetik ortalamaları incelendiğinde, genel olarak gelir düzeyi düşük olanların daha fazla önemli sanal kaytarma faaliyetlerinde bulunduğu şeklinde yorumlanabilir. Çalışanların önemsiz sanal kaytarma faaliyetleri ile ilgili sorulara verdikleri yanıtların aritmetik ortalamaları incelendiğinde ise, genel olarak gelir düzeyi yüksek olanların daha fazla önemsiz sanal kaytarma faaliyetlerinde bulunduğu şeklinde yorumlanabilir. $\mathrm{H}$ hipotezi $\% 95$ güven aralığında önemli sanal kaytấrma boyutu $(p=0,012)$ ve önemsiz sanal kaytarma $(p=0,004)$ boyutu açısından desteklenmiştir.

Tablo 7: Aylık Gelir Durumuna İlişkin Tek Yönlü Varyans Analizi Tablosu

\begin{tabular}{|c|c|c|c|c|c|c|}
\hline \multicolumn{2}{|c|}{ Sanal Kaytarma Boyutları } & Kareler & Serbestlik & Kareler & $\mathrm{F}$ & P değeri \\
\hline \multirow{3}{*}{$\begin{array}{l}\text { Önemsiz } \\
\text { Sanal } \\
\text { Kaytarma }\end{array}$} & Gruplararası & 11,543 & 3 & 3,848 & \multirow[t]{3}{*}{4,663} & \multirow[t]{3}{*}{$0,004^{*}$} \\
\hline & Gruplariçi & 121,287 & 147 & 0,825 & & \\
\hline & Toplam & 132,830 & 150 & & & \\
\hline \multirow{3}{*}{$\begin{array}{l}\text { Önemli Sanal } \\
\text { Kaytarma }\end{array}$} & Gruplararası & 6,395 & 3 & 2,132 & \multirow[t]{3}{*}{3,768} & \multirow[t]{3}{*}{$0,012^{*}$} \\
\hline & Gruplariçi & 83,147 & 147 & 0,566 & & \\
\hline & Toplam & 89,542 & 150 & & & \\
\hline
\end{tabular}

(Not:* $p<0,05$ )

Tablo 8: İş Dışı Günlük Internet ve Bilgisayar Kullanımına İlişkin Tek Yönlü Varyans Analizi Tablosu

\begin{tabular}{|c|c|c|c|c|c|c|}
\hline \multicolumn{2}{|c|}{ Sanal Kaytarma Boyutları } & Kareler & Serbestlik & Kareler & $\mathrm{F}$ & P değeri \\
\hline \multirow{3}{*}{$\begin{array}{l}\text { Önemsiz } \\
\text { Sanal } \\
\text { Kaytarma }\end{array}$} & Gruplararası & 20,446 & 4 & 5,111 & \multirow[t]{3}{*}{6,640} & \multirow[t]{3}{*}{$0,000^{*}$} \\
\hline & Gruplariçi & 112,385 & 146 & 0,770 & & \\
\hline & Toplam & 132,830 & 150 & & & \\
\hline \multirow{3}{*}{$\begin{array}{l}\text { Önemli Sanal } \\
\text { Kaytarma }\end{array}$} & Gruplararası & 10,164 & 4 & 2,541 & \multirow[t]{3}{*}{4,674} & \multirow[t]{3}{*}{$0,001^{*}$} \\
\hline & Gruplariçi & 79,378 & 146 & 0,544 & & \\
\hline & Toplam & 89,542 & 150 & & & \\
\hline
\end{tabular}

(Not: $\left.{ }^{*} p<0,05\right)$ 
$\mathrm{H}_{1 \mathrm{~g}}$ hipotezinitestetmekamacıylatekyönlüvaryans analizinden faydalanılmıştır. Analiz verileri Tablo 8'de gösterilmektedir. Analiz sonucunda, iş saatlerinde iş dışı günlük internet ve bilgisayar kullanma durumu ile önemli ve önemsiz sanal kaytarma faaliyetleri arasında istatistiksel açıdan anlamlı derecede bir farklılık saptanmıştır. Çalışanların önemli ve önemsiz sanal kaytarma faaliyetleri ile ilgili sorulara verdikleri yanıtların aritmetik ortalamaları incelendiğinde, genel olarak iş saatlerinde iş dışı günlük internet ve bilgisayar kullanma süresi yüksek olanların daha fazla önemli ve önemsiz sanal kaytarma faaliyetlerinde bulunduğu şeklinde yorumlanabilir. $\mathrm{H}_{1 \mathrm{~g}}$ hipotezi \%95 güven aralığında önemli sanal kaytarma boyutu $(p=0,001)$ ve önemsiz sanal kaytarma $(p=0,000)$ boyutu açısından desteklenmiştir.

$\mathrm{H}$ hipotezini test etmek amaciyla Pearson Korelasyon analizinden faydalanılmıştır. Analiz verileri Tablo 9'da gösterilmektedir.Tablo 9'da önemli sanal kaytarma faaliyetleri ile önemsiz sanal kaytarma faaliyetleri arasında orta $(r=0,546)$ derecede pozitif yönlü ve anlamlı bir ilişkinin olduğu saptanmıştır. Anlamlı boyutlara ait tanımlayıcı istatistiklerin soru bazında ve boyut bazında gösterildiği Tablo 1'deki verilerden faydalanıldığında, "önemsiz sanal kaytarma faaliyetlerine $(\bar{X}=3.17)$ " orta derecede, "önemli sanal kaytarma faaliyetlerine $(\bar{X}=2.12)$ " ise düşük derecede katıldıkları gözlenmektedir. Kaplan ve Öğüt (2012: 594) tarafından yapılan araştırma da, çalışanları "önemsiz sanal kaytarma faaliyetlerine ( $\bar{X}=3.38)$ " orta derecede, "önemli sanal kaytarma faaliyetlerine $(\bar{X}=2.10)$ " ise düşük derecede katıldıkları gözlenmektedir. Çalışanların orta derecede katıldıkları "önemsiz sanal kaytarma faaliyetlerinin" soru bazındaki ortalamaları incelendiğinde, iş dışı haberleşme için e-posta alma, gönderme veya kontrol etme, internet üzerinden haber sitelerini ziyaret etme (gazete, online haber TV'leri ve diğer haber siteleri) ve internet üzerinden bankacılık işletmeleri yapmanın (EFT, havale işlemleri gibi) yüksek olduğu gözlenmektedir. Çalışanların düşük derecede kaldıkları "önemli sanal kaytarma faaliyetlerinin" soru bazındaki aritmetik ortalamaları incelendiğinde ise, sosyal içerikli ağlara katılmanın (Facebook, Twitter vb.) ve internet üzerinden eğlence amaçlı video seyretmenin (YouTube veya zapkolik gibi) diğer önemli sanal kaytarma faaliyetlerine göre daha fazla olduğu gözlenmektedir.

Tablo 9: Sanal Kaytarma Tipleri Arasındaki Korelasyonlar

\begin{tabular}{|l|l|l|}
\hline Sanal Kaytarma Boyutları & 1 & 2 \\
\hline Önemsiz Sanal Kaytarma & 1 & $0,546^{* *}$ \\
\hline Önemli Sanal Kaytarma & $0,546^{* *}$ & 1 \\
\hline
\end{tabular}

( Not: **p<0.01 (Çift Yönlü) )
$\mathrm{H}$ hipotezi \%95 güven aralığında önemsiz sanal kaytarma faaliyetleri ile önemli sanal kaytarma faaliyetleri arasındaki ilişki $(r=0,546)$ açısından desteklenmiştir.

\section{TARTIŞMA VE SONUÇ}

\subsection{Tartışma}

Çalışanların önemli ve önemsiz sanal kaytarma faaliyetlerini kullanma sıklığı cinsiyet değişkeni açısından anlamlı bir farklılık göstermemiştir. Üniversite çalışanları açısından bu hipotez beklenildiği şekilde sonuçlanmamıştır. Üniversitelerin diğer işletme ve kurumlara göre daha özerk bir yapıda olması erkek ve kadın çalışanlar arasında üniversitenin daha demokratik bir ortam olarak algılanmasına neden olabilmektedir. Böylece maskülen bir örgüt yapısı yerine daha demokratik bir örgüt yapısı çalışanlar arasında anlamlı bir farklılık yaratmamış olabilir. Stanton(2002) ve Ugrin vd. (2007: 86) tarafından yapılan araştırmalarda cinsiyet açısından anlamlı bir farklılık görülmemiş̧ir. Restubog vd. (2011) tarafından yapılan araştırmada da cinsiyetin sanal kaytarmayı etkilemediği sonucuna ulaşılmıştır. Bu sonuçların araştırmadaki sonuç ile paralel çıkması üniversite personeli için de bu sonucun genelleştirilebilme sonucunu doğurabilir. Çünkü mühendis, yönetici ve üniversite çalışanlarını içeren bu örneklemlerin daha özerk yapıda bilgi çalışanları olduğu düşünülürse bu anlamda bir benzerlik kurulabilir.

Çalışanların önemli sanal kaytarma faaliyetlerini kullanma sıklığı medeni durum değişkeni açısından anlamlı bir farklılık göstermiştir. Çalışanların bekâr veya evli olmaları internet ve bilgisayar kullanma alışkanlıklarında da değişiklik yaratmıştır. Tablo 3'deki ortalamalar incelendiğinde bekâr çalışanların evli çalışanlardan daha fazla önemli sanal kaytarma faaliyetine katıldıkları gözlenmektedir.Bekâr çalışanların yaşamsal anlamda daha farklı ve daha geniş zamana sahip olmaları intiyaçlarını da çeşitlendirmektedir. Internet ve bilgisayar teknolojisinin de bu ihtiyaçları sağlayabilecek etkili bir araç olması, medeni durum açısından bekâr ve evliler arasında anlamlı farklılıklar yaratabilmektedir. Medeni durum ile önemli sanal kaytarma faaliyetleri arasındaki soru bazında alınan çapraz tablolar neticesinde bekâr çalışanların özellikle Tablo 1'de yer alan 1-5 arasında yer alan sosyal içerikli ağlara katılma, sanal toplulukları ziyaret etme, eğlence amaçlı video seyretme, blogları okuma ve müzik, film, video ve doküman indirme faaliyetlerini daha yoğun olarak kullandıkları gözlenmiştir. Bu kullanım amaçlarıyla bekâr çalışanların, sanal alemin kendilerine sunmuş olduğu eğlenceli ortamı, zamanlarının da onlara verdiği imkanlar ölçüsünde aktif 
olarak kullandıkları söylenebilir. Ancak önemsiz sanal kaytarma faaliyetlerini kullanma sıklığı açısından ise, medeni durum değişkeni açısından anlamlı bir farklılık gözlenmemiştir.

Çalışanların önemli ve önemsiz sanal kaytarma faaliyetlerini kullanma sıkığı statü değişkeni açısından anlamlı bir farklılık göstermiştir. Önemsiz ve önemli sanal kaytarma faaliyetlerine akademik personelin daha yüksek düzeyde katıldığı saptanmıştır. Köse vd. (2012) tarafından yapılan araştırmada da akademik personelin (araştırma görevlisi) çeşitli amaçlarla sanal kaytarma yaptıkları belirlenmiştir. Özkalp vd. (2012) tarafından yapılan araştırmada, akademik personelin genel amaçlı dolaşma hariç, diğer kaytarma davranışlarını daha fazla yaptıkları belirlenmiştir. Garrett ve Dangizer (2008) ve Ugrin vd. (2007) tarafından yapılan araştırmada da üst düzey yönetim kadrosundaki çalışanların sanal kaytarma eğilimleri daha yüksek çıkmıştır. Çapraz tablolar yardımıyla akademik personelin önemsiz sanal kaytarma faaliyetlerinde bulundukları ifadeler incelendiğinde, yatırımla ilgili web siteleri hariç diğer kaytarma faaliyetlere yüksek derecede katıldıkları gözlenmektedir.

Çalışanların önemli ve önemsiz sanal kaytarma faaliyetlerini kullanma sıklığı yaş değişkeni açısından anlamlı bir farklııık göstermiştir. Genç çalışanların önemli ve önemsiz sanal kaytarma faaliyetlerine yaşça büyük çalışanlara göre daha yüksek derecede katıldıkları gözlenmiştir. Yaş ile ilgili yapılan araştırmalarda da genç çalışanların daha fazla sanal kaytarma yaptıkları saptanmıştır (Mastrangelo vd., 2006; Phillips ve Reddie, 2007;Vitak vd., 2011; Atkin vd., 1998; Kraut vd., 1998; Matanda vd., 2004; Ugrin vd., 2007; Köse vd., 2012). Genç çalışanların bilgi ve iletişim teknolojilerinin eğlence yönlerini baz alarak kaytarma eyleminde bulundukları söylenebilir. Bir anlamda internetin sunduğu olanaklardan (e-mail almadan sosyal içerikli ağlara katılmaya kadar)yaratacağı sorunlar düşünülmeden faydalanıldığı söylenebilir.

Çalışanların önemli ve önemsiz sanal kaytarma faaliyetlerini kullanma sıklığı eğitim durumu değişkeni açısından anlamlı bir farklılık göstermiştir. Araştırmada eğitim düzeyi arttıkça önemsiz sanal kaytarma faaliyetlerinde bulunma sıklığı artmıştır. Diğer yandan lisans mezunlarının diğer eğitim düzeyinde olanlara göre daha fazla önemli sanal kaytarma faaliyetlerinde bulunduğu saptanmıştır. Eğitim durumu ile ilgili yapılan çalışmalarda da (Atkin vd., 1998; Garrett ve Dangizer, 2008; Özkalp vd., 2012) eğitim durumu ile kaytarma faaliyetleri arasında anlamlı ilişkiler bulunmuş̧ur. Çalışanların eğitim düzeyi arttıkça iş dışı e-mail kullanım oranının artması (Phillips ve Reddie, 2007) ve interneti iletişim amaçı kullanması (Matan- da vd., 2004) araştırma sonucunu desteklemektedir. Aynı zamanda eğitim düzeyi düştükçe önemli sanal kaytarma faaliyetlerini kullanma sıklığının artması da eğitim düzeyidüşük çalışanların sanal alemin tehlikelerinin ve getireceği hukuki sonuçların farkında olmamasından kaynaklanabilir.

Çalışanların önemli ve önemsiz sanal kaytarma faaliyetlerini kullanma sıklığı aylık gelir değişkeni açısından anlamlı bir farklılık göstermiştir. Araştırmada, çalışanlar gelir düzeyleri arttıkça daha çok önemsiz sanal kaytarma faaliyetlerine bulunurken, gelir düzeyleri düştükçe ise daha çok önemli sanal kaytarma faaliyetlerinde bulunmuştur. Garrett ve Dangizer (2008) tarafından yapılan araştırmada da gelir arttıkça sanal kaytarma faaliyetlerinde bulunma sıklığının arttığı saptanmıştır. Bu çalışmada ortaya çıkan sonuç önemsiz sanal kaytarma ile ilgili çıkan sonucu desteklemektedir. Çalışanların gelir kaynaklarının artması, tüketim ve yaşam alışkanlıklarının değişmesine katkı sağlamaktadır. Bilgisayar ve iletişim teknolojilerinin gelişmesi de bu amaçlara hizmet eden önemli bir araç olarak ortaya çıkmaktadır.

Çalışanların önemli ve önemsiz sanal kaytarma faaliyetlerinde bulunmaları, iş saatlerinde iş dışı internet ve bilgisayar kullanma süresindeki (süre/günlük) değişime göre anlamlı bir farklılık göstermiştir. Araştırmada iş saatlerinde iş dışı internet ve bilgisayar kullanma süresi arttıkça, önemli ve önemsiz sanal kaytarma faaliyetlerinin de arttığı sonucuna ulaşılmıştır. İş içerisinde sürekli bilgisayar kullanan çalışanlarda sanal kaytarma faaliyetlerini kullanma sıklığı daha yüksek düzeyde görülmektedir (Vitak vd., 2011). Mastrangelo vd. (2006) tarafından yapılan araştırmada da daha uzun süre internet erişimi olan ve evden daha hızlı internet bağlantısı olan çalışanların yıkıcı/ önemli sanal kaytarma eğilimlerinin daha fazla olduğu saptanmıştır. İnternet ve bilgisayar karşısında geçirilen süre arttıkça çalışanlar bu süre içerisinde gerek önemli gerekse de önemsiz sanal kaytarma yapmayı kendilerine bir hak olarak görebilmektedirler. İşin parçası olan bu teknolojiler kullanıcıya işini zamanında tamamladığı sürece kaytarma faaliyetlerini yapmasının bir sakıncası olmadığı duygusunu uyandırabilir. Ancak sanal kaytarmanın işletme ve çalışanlar açısından kayıpları düşünüldüğünde harcanan sürenin önemi daha da artmaktadır.

Çalışanların önemli ve önemsiz sanal kaytarma faaliyetlerini kullanma sıklığı arasında pozitif ve anlamlı bir ilişki gözlenmiştir. Mastrangelo vd. (2006) tarafından yapılan araştırmada, yıkıcı/önemli sanal kaytarma faaliyetlerinde bulunanların üretkenlik karşıtı/önemsiz sanal kaytarma faaliyetlerinde de 
bulundukları saptanmıştır. Kaplan ve Öğüt (2012: 594) tarafından yapılan araştırmada da önemli ve önemsiz sanal kaytarma faaliyetleri arasında pozitif yönlü ve anlamlı bir ilişki gözlenmiştir. Bu çalışmalarda ortaya çıkan sonuçlar, önemli ve önemsiz sanal kaytarma arasındaki pozitif ilişki ile ilgili çıkan sonucu desteklemektedir. İş dışı bilgisayar ve internet kullanma süresi yüksek, genç ve akademik personelin hem önemsiz hem de önemli sanal kaytarma faaliyetlerinde bulunma sıklığının yüksek olması da bu sonucu destekler niteliktedir.

\subsection{Sonuç}

Araştırma sonuçlarından yola çıkılarak, genç ve akademik personel olan çalışanların her iki kaytarma faaliyetleri açısından; bekâr, lisans mezunu çalışanların ve gelir düzeyi düşük olanların önemli; eğitim düzeyi ve gelir düzeyi yüksek çalışanların ise önemsiz sanal kaytarma faaliyetleri açısından internet ve bilgisayar kullanımı hususunda yeterli bilince kavuşturulmasında yarar vardır. Bunun yanında çeşitli internet-filtreleme uygulamaları ve çalışanların haysiyetine ve mahremiyetine uygun internet izleme sistemleri (Eivazi, 2011: 523; Greenfield ve Davis, 2002: 348) de etkili yöntemler arasında sayılabilir. Illave olarak iş stresini azaltmaya yönelik stres yönetimi politikalarının geliştirilmesi (Ugrin vd., 2007; Lavoie ve Pychyl, 2001; Anandarajan vd., 2004: 71; Stanton, 2002: 57; Block, 2001: 226; Ovarec, 2001: 61) ve uygun internet-yönetimi politikasının (Flynn, 2001: 49-60; Greenfield ve Davis, 2002: 348) oluşturulması, sanal kaytarma uygulamalarının negatif sonuçlarından korunmanın etkili uygulamaları arasında sayılabilir. Çünkü bu uygulamalar çalışanların yanlış internet kullanımlarıyla açılan davalar nezdinde işletmeleri ve işletme sahiplerini mahkemelerce koruyacak etkili önlemlerdir. Işletmelerde potansiyel problemlerin tespit edilip çalışanları sanal kaytarmaya iten değişkenlerin tespit edilmesi, sanal kaytarmayı azaltabilecek uygulamalar arasında değerlendirilebilir (Özkalp vd., 2012: 31-32). Kaplan ve Öğüt (2012) tarafından yapılan araştırmada örgütsel adalet ile önemli ve önemsiz sanal kaytarma davranışları arasında negatif yönlü ve anlamlı bir ilişki gözlenmiştir. İsverenlerin adaletliyaklaşımlarının sanal kaytarma davranışlarını azaltacağı da göz önünde bulundurulmalıdır. Köse vd. (2012) tarafından yapılan araştırmada, sosyal kolaylaştırma -etrafta başka bir çalışma arkadaşının bulunmasının- kavramının diğer bir anlatımla da başkaları tarafından izleniyor olmanın sanal kaytarma davranışlarını azalttığı sonucuna ulaşılmıştır. Çalışanların başkalarının izlemesi dürtüsüyle kendilerini çalışmak zorunda hissettikleri, böylece zamanlarını daha verimli kullandıkları (sanal kaytarma yapmadan kendilerini alıkoyan) ve performanslarının arttığı sonucuna ulaşılmıştır. Ancak yoğun zihinsel işler gerektiren durumlarda ise yalnız kalmayı tercih ettikleri belirlenmiştir. Bu sonuçtan hareketle çalışanların yoğun zihinsel işleri gerektiren işlerde evden çalışmalarının (home office- sanal ofis), ancak rutin ve iyi öğrenilmiş işlerde ise birlikte çalışmalarının sanal kaytarmayı önleyici bir uygulama olabileceği önerilmiştir (Köse vd., 2012: 294). Ancak çalışanlardaki iş saatlerinde iş dışı bilgisayar ve internet kullanımı sadece bu konuda yeterli bilincin olup olmamasına da bağlı olmayabilir. Internet ve mobil teknolojilere bağımlılık son zamanlarda üzerinde durulan bir konu olarak ortaya çıkmıştır. Bu bağlamda psikoteknik yöntemler yardımıyla, personel alımlarında sanal kaytarma potansiyeli yüksek olabilecek çalışanların belirlenmesi ve işletmeye alınmaması yoluna gidilebilir (Mills vd., 2001; Whitty ve Carr, 2006). Ayrıca hâlihazırdaki çalışanlardan sanal kaytarma potansiyeli yüksek olanların, sanal kaytarmanın işletmelerde oluşturacağı maliyet kayıpları ve hukuki yaptırımları konusunda da bilgilendirilmesinde yarar vardır. Çünkü söz konusu bilgilendirme yapıldığında ve ilgili uyarılar işyeri iç yönetmeliklerine (işyeri etik kuralları olarak) eklendiğinde, ancak çalışanlar bunlara uygun hareket etmediklerinde iş akitlerinin fesih edilmesi sonucu ile karşılaşabileceklerdir. İş saatlerinde iş dışı internet ve bilgisayar kullanımına bir çözüm getirilmedikçe, işletme içerisinde sanal kaytarma yapan çalışanların sayısı da artacaktır. Bu durumda işletmeler önemli maliyet ve verimlilik kayıplarıyla karşılaşacak ve örgütsel etkinlik de bu durumdan olumsuz olarak etkilenecektir (Stanton, 2002: 56).

Çalışanların iş saatlerinde iş dışı amaçlarla sanal kaytarma yaptıklarını ifade etmeleri zor olduğundan dolayı örneklem veri büyüklüğü sınırlı kalmıştır. Bu nedenle araştırma verilerinin büyük örneklemlerde ve farklı sektörlerde sınanmasında yarar vardır. Araştırma kapsamında elde edilen bulguların Türkiye genelindeki üniversite çalışanlarının görüşlerini yansıtma iddiası yoktur. Araştırma kapsamında çalışanları sanal kaytarmaya iten psikolojik süreçlerden bahsedilmemiştir. Bu psikolojik süreçlerin incelenmesi konuya farklı bir bakış açısı katabilir. 


\section{KAYNAKLAR}

Altunışık, R., Coşkun, R., Bayraktaroğlu, S. ve Yıldırım, E. (2010)Sosyal Bilimlerde Araştırma Yöntemleri, SPSS Uygulamal,, 6. Baskı, Ankara, Pegem Akademi.

Anandarajan, M., Devine, P. ve Simmers, C. A. (2004) "A Multidimensional Sealing Approach to Personal Web Usage in the Workplace" M. Anandarajan ve C. A. Simmers (eds.), A Personal Web Usage in the Workplace: A Guide to Effective Human Resources Management, 1st Edition, Hensey, Information Science Publishing.

Atkin, D., Jeffres, L. ve Neuendorf, K. (1998) "Understanding Internet Adoption as Telecommunications Behavior" Journal of Broadcasting \& Electronic Media, 42(4):475-490.

Blanchard, A.L. ve Henle, C.A. (2008) "Correlates of Different Forms of Cyberloafing: The Role of Norms and External Locus of Control"Computers in Human Behavior, 24(3):1067-1084.

Block, W. (2001) "Cyberslacking, Business Ethics and Managerial Economics" Journal of Business Ethics, 33(3):225-231.

Çokluk, Ö., Şekercioğlu, G. ve Büyüköztürk, Ş. (2012)Sosyal Bilimler İ̧̧in Çok Değişkenli İstatistik: SPSS ve LISREL Uygulamalar,2. Baskı, Sakarya, Sakarya Yayıncilik.

Eivazi, K. (2011) “Computer Use Monitoring and Privacy at Work"Computer Law \& Security Review, 27(5):516-523.

Flynn, N. (2001) E-Policy Handbook: Designing and Implementing Effective E-Mail, Internet and Software Policies, 1st Edition, Saranac Lake, AMACOM Books.

Garrett, R.K., ve Danziger, J.N. (2008) “On Cyberslacking: Workplace Status and Personal Internet Use at Work" CyberPsychology \& Behavior, 11(3):287-292.

Greenfield, B.N.ve Davis, R.A. (2002) "Lost in Cyberspace: The Web@Work" Cyberpsychology and Behavior, 5(4):347-353.

Greengard, S. (2000) "The High Cost of CyberslackingEmployees Waste Time Online” Workforce, 79(12):22-24.

Habing, B. (2005) "Exploratory Factor Analysis" http://www.stat.sc.edu/ - habing/courses/530/EFA2005. pdf, (28.07.2013).

İnce, M. ve Gül, H. (2011) "The Relation of Cyber Slacking Behaviors with Various Organizational Outputs: Example of Karamanoğlu Mehmetbey University" European Journal of Scientific Research, 52(4):507-527.

Kalaycı, E. (2010) "Üniversite Öğrencilerinin Siber Aylaklık Davranışları İle Öz Düzenleme Stratejileri
Arasındaki İlişkilerin İncelenmesi"Yayınlanmamış Yüksek Lisans Tezi, Ankara Hacettepe ÜniversitesiFen Bilimleri Enstitüsü.

Kaplan, M. ve Öğüt, A. (2012) “Algılanan Örgütsel Adalet İle Sanal Kaytarma Arasındaki İlişkinin Analizi: Hastane Çalışanları Örneği”Dokuz Eylül Üniversitesi 20. Yönetim ve Organizasyon Kongresi Bildiriler Kitabı: 592596.

Kaya, Z. (2012) “İşveren Tarafından Bilgisayarların Takip Edilmesi ve İnternet Sebebiyle İş Sözleşmesinin Feshi” http://www.zinnurkaya.av.tr/makale/9/ isVEREN-TARAFiNDAN-BiLGiSAYARLARiNTAKiP-EDiLMESi-VE-iNTERNET-SEBEBiYLE-isSoZLEsMESiNiN-FESHi, (06.07.2013).

Kim, S.J. ve Byrne, S. (2011) "Conceptualizing Personal Web Usage in Work Contexts: A Preliminary Framework" Computers in Human Behavior, 27(6):22712283.

Köse, S., Oral, L. ve Türesin, H. (2012) "İş Yaşamında Sosyal Kolaylaştırma Kavramı ve Sanal Kaytarma ile İlişkisi: Araştırma Görevlileri Üzerinde Bir Araştırma" Sosyal ve Beşeri Bilimler Dergisi, 4(1):287-295.

Kraut, R., Patterson, M., Lundmark, V., Kiesler, S., Mukopadhyay, T. ve Scherlis, W. (1998)“Internet Paradox: A Social Technology That Reduces Social Involvement and Psychological Well Being?"American Psychologist, 53(9):1017-1031.

Kurt, M. (2011) "Siber Aylaklık Davranışlarının Karşılaştırmalı Olarak İncelenmesi” Fırat University $5^{\text {th }}$ International Computer \& Instructional Technologies Symposium, September 22-24, Elazı̆̆.

Lavoie, J.A.A. ve Pychyl, T.A. (2001) "Cyberslacking and the Procrastination Superhighway: A Web-Based Survey in Online Procrastination, Attitudes, and Emotion" Social Science Computer Review, 19(4):431-444.

Lim, V.K.G. (2002)“The IT Way of Loafing on the Job: Cyberloafing, Neutralizing and Organizational Justice" Journal of Organizational Behavior, 23(5):675694.

Mahatanankoon, P. ve Igbaria, M. (2004) "Impact of Personal Internet Usage on Employee's Well-Being” Anandarajan (eds.)A Personal Web Usage in the Workplace: A Guide to Effective Human Resources Management, 1st Edition, Hensey, Information Science Publishing.

Mastrangelo, P.M., Everton, W. ve Jolton, J.A. (2006) "Personal Use of Work Computers: Distraction versus Destruction" CyberPsychology \& Behavior, 9(6):730-741. 
Matanda, M., Jenvey, V.B. ve Phillips, J.G. (2004) "Internet Usage in Adulthood: Loneliness, Computer Anxiety and Education"Behavior Change, 21(2):103-114.

Mills, J.E., Hu, B., Beldona, S. ve Clay, J. (2001) "Cyberslacking! A Wired-Workplace Liability Issue" The Cornell Hotel and Restaurant Administration Quarterly, 42(5):34-47.

Morahan-Martin, J. (1998) "The Gender Gap in Internet Use: Why Men Use the Internet More Than Women-A Literature Review" CyberPsychology \& Behavior, 1(1):3-10.

MYPP (2012) 2012 Mali Yılı Performans Programı, http://strateji.balikesir.edu.tr/portal/performans.pdf, 18 Temmuz 2012.

Oravec, J.A. (2002) "Constructive Approaches to Internet Recreation in the Workplace" Communications of the ACM, 45(1):60-63.

Özkalp, E., Aydın, U. ve Tekeli, S. (2012)“Sapkın Örgütsel Davranışlar ve Çalışma Yaşamında Yeni Bir Olgu: Sanal Kaytarma (Cyberloafing) ve İş İlişkilerine Etkileri” Çimento İşveren Sendikası Dergisi, 26(2):18-33.

Phillips, J.G. ve Reddie, L. (2007) "Decisional Style and Self-Reported Email Use in the Workplace" Computers in Human Behavior, 23(5):2414-2428.

Restubog, S.L.D., Garcia, P.R.J.M., Toledano, L.S., Amarnani, R.K., Tolentino, L.R. ve Tang, R.L. (2011)"Yielding to (Cyber)-Temptation: Exploring the Buffering Role of Self-Control in the Relationship between Organizational Justice and Cyberloafing Behavior in the Workplace"Journal of Research in Personality, 45(2):247-251.

Richardson, K. ve Benbunan-Fich, R. (2011) "Examining the Antecedents of Work Connectivity Behavior during No-Work Time" Information and Organization, 21(3):142-160.

Staff Report (2010) Cyberslacking at an All Time High in the Workplace, Jackson NJ Online, http://www. jacksonnjonline.com/2010/01/07/cyberslacking-at-an-alltime-high-in-the-workplace/11412/, 18 Temmuz 2012.
Stanton, J.M. (2002)"Company Profile of the Frequent Internet User"Communications of the ACM, 45(1):55-59.

TCK (2004) Türk Ceza Kanunu, http://www.tbmm. gov.tr/kanunlar/k5237.html, (11.07.2013).

TÜİK (2012) Türkiye İstatistik Kurumu Hanehalkı Bilişim Teknolojileri Kullanım Araştırması, http:// www.tuik.gov.tr/PreHaberBultenleri.do?id=10880, (11.12.2012).

Ugrin, J.C., Pearson, J.M. ve Odom, M.D. (2007) "Profiling Cyber-Slackers in the Workplace: Demographic, Cultural, and Workplace Factors"Journal of Internet Commerce, 6(3):75-89.

Vitak, J., Crouse, J. ve LaRose, R. (2011)"Personal Internet Use at Work: Understanding Cyberslacking" Computers in Human Behavior, 27(5): 1751-1759.

Wallace, P. (2004) The Internet in the Workplace: How New Technology Is Transforming Work,1st Edition, New York, Cambridge University Press.

Weatherbee, T.G. (2010) "Counterproductive Use of Technology at Work: Information \& Communications Technologies and Cyberdeviancy" Human Resource Management Review, 20(1): 35-44.

LEGALBANK (2012) "Yargıtay 9. Hukuk Dairesi Kararları” (http://legalbank.net/mahkeme-kararlari/ yargitay-9-hukuk-dairesi-kararlari, (10.07.2013).

İş HUKUKU ENSTITÜSÜ (2012) “İşçinin İş Amaçlı Bilgisayarını İş Dışındaki Amaçlarla Kullanması” http://www.kurumsalhaberler.com/ishukukuenstitusu/ bultenler/iscinin-is-amacli-bilgisayarini-is-disindakiamaclarla-kullanmasi/, (11.07.2013).

Whitty, M.T. ve Carr, A.N. (2006) "New Rules in the Workplace: Applying Object-Relations Theory to Explain Problem Internet and Email Behavior in the Workplace"Computers in Human Behavior, 22(2):235250. 